Original Investigation

\title{
Puma spatial ecology in open habitats with aggregate prey
}

\author{
L. Mark Elbroch ${ }^{\mathrm{a}, *}$, Heiko U. Wittmer ${ }^{\mathrm{a}, \mathrm{b}}$ \\ a Wildlife, Fish, and Conservation Biology, University of California, One Shields Ave., Davis, CA 95616, USA \\ b School of Biological Sciences, Victoria University of Wellington, PO Box 600, Wellington 6140, New Zealand
}

\section{A R T I C L E I N F O}

\section{Article history:}

Received 28 September 2011

Accepted 28 February 2012

\section{Keywords:}

Home range

Lama guanicoe

Patagonia

Puma concolor

Resource use

\begin{abstract}
A B S T R A C T
Solitary felids are commonly associated with structurally complex habitats, where their foraging success is attributed to stealth and remaining undetected by competitive scavengers. Research in North America suggests that pumas (Puma concolor), a wide-ranging species found throughout the Americas, conform to the general characteristics of solitary felids and avoid open grasslands with aggregating prey. Researchers hypothesize that pumas are limited to structurally complex habitats in North America because of pressures from other large, terrestrial competitors. We explored the spatial ecology of pumas in open habitat with aggregating prey in Chilean Patagonia, where pumas lack large, terrestrial competitors. We tracked 11 pumas over 30 months (intensive location data for 9 pumas with GPS collars for $9.33 \pm 5.66$ months each) in an area where mixed steppe grasslands composed $53 \%$ of the study area and carried $98 \%$ of available prey biomass, to track resource use relative to availability, assess daily movements, quantify home ranges and calculate their density. As determined by location data and kill sites, Patagonia pumas were primarily associated with open habitats with high prey biomass, but at finer scales, preferentially selected for habitat with complex structure. On average, pumas traveled $13.42 \pm 2.50 \mathrm{~km}$ per day. Estimated $95 \%$ fixed kernel home ranges averaged $98 \pm 31.8 \mathrm{~km}^{2}$ for females and $211 \pm 138.8 \mathrm{~km}^{2}$ for males, with high spatial overlap within and between the sexes. In a multivariate analysis, available prey biomass was the strongest predictor of variation in the size of an individual puma's home range. Finally, we determined a total puma density of 3.44 pumas $/ 100 \mathrm{~km}^{2}$, a significantly smaller estimate than previously reported for Patagonia, but similar to densities reported for North America.
\end{abstract}

(c) 2012 Deutsche Gesellschaft für Säugetierkunde. Published by Elsevier GmbH. All rights reserved.

\section{Introduction}

Solitary felids are typically associated with structurally complex habitats in which they can remain "inconspicuous" (Lamprecht, 1978 ) and in which ungulate prey tend to be solitary or aggregate in small groups (Laundré, 2010; Logan and Sweanor, 2010). Solitary felids use habitat structure to their advantage to more successfully stalk and ambush prey (Lamprecht, 1978; Murphy and Ruth, 2010). They also drag their prey into areas of greater cover and/or hide prey remains under a layer of debris to minimize detection by competitive scavengers (Hayward et al., 2006; Murphy and Ruth, 2010).

The puma (Puma concolor) is a solitary felid, with the largest distribution of any terrestrial mammal in the western hemisphere (Sunquist and Sunquist, 2002). Pumas exhibit extreme behavioral plasticity and inhabit every forest type across their range, as well as montane deserts, lowland deserts with broken terrain, and Mediterranean systems (Beier, 2010; MacDonald and Loveridge, 2010). Research in North America suggests that pumas conform

\footnotetext{
* Corresponding author. Tel.: +1 207240 8550; fax: +1 5307524154

E-mail address: lmelbroch@ucdavis.edu (L.M. Elbroch).
}

to the general characteristics of solitary felids, in that they avoid open grasslands with aggregating prey like pronghorn (Antilocapra americana) and/or bison (Bison bison) (Ernest et al., 2003; Riley et al., 2004; McRae et al., 2005). However, researchers hypothesize that it was the historic presence of large, terrestrial competitors (gray wolves, Canis lupus, and bears, Ursus spp.) that limited pumas to more complex habitats rather than an inherent avoidance of these habitats per se (Riley et al., 2004; Ruth and Murphy, 2010). Recent research in Yellowstone National Park supports this hypothesis, for resident pumas began "concentrating their activities" in more structurally complex habitats with the reintroduction and spread of wolves in the system (Ruth et al., 2011). Given the broad distribution of pumas, however, the question remains as to the spatial ecology of pumas inhabiting predominantly open habitats with aggregating prey in the far south, where they do not compete with large, terrestrial competitors.

Patagonia is a vast $1,000,000 \mathrm{~km}^{2}$, sparsely-populated region below latitude $39^{\circ} \mathrm{S}$ in southern Chile and Argentina. Excepting the moist forests forming its western border, Patagonia is largely dry, open steppe inhabited by native guanacos (Lama guanicoe), ungulates weighing up to $120 \mathrm{~kg}$ that aggregate in large social groups (Bank et al., 2003), and flocks of exotic domestic sheep (Ovis aries) (Novaro et al., 2000). To date, only one telemetry study on pumas 


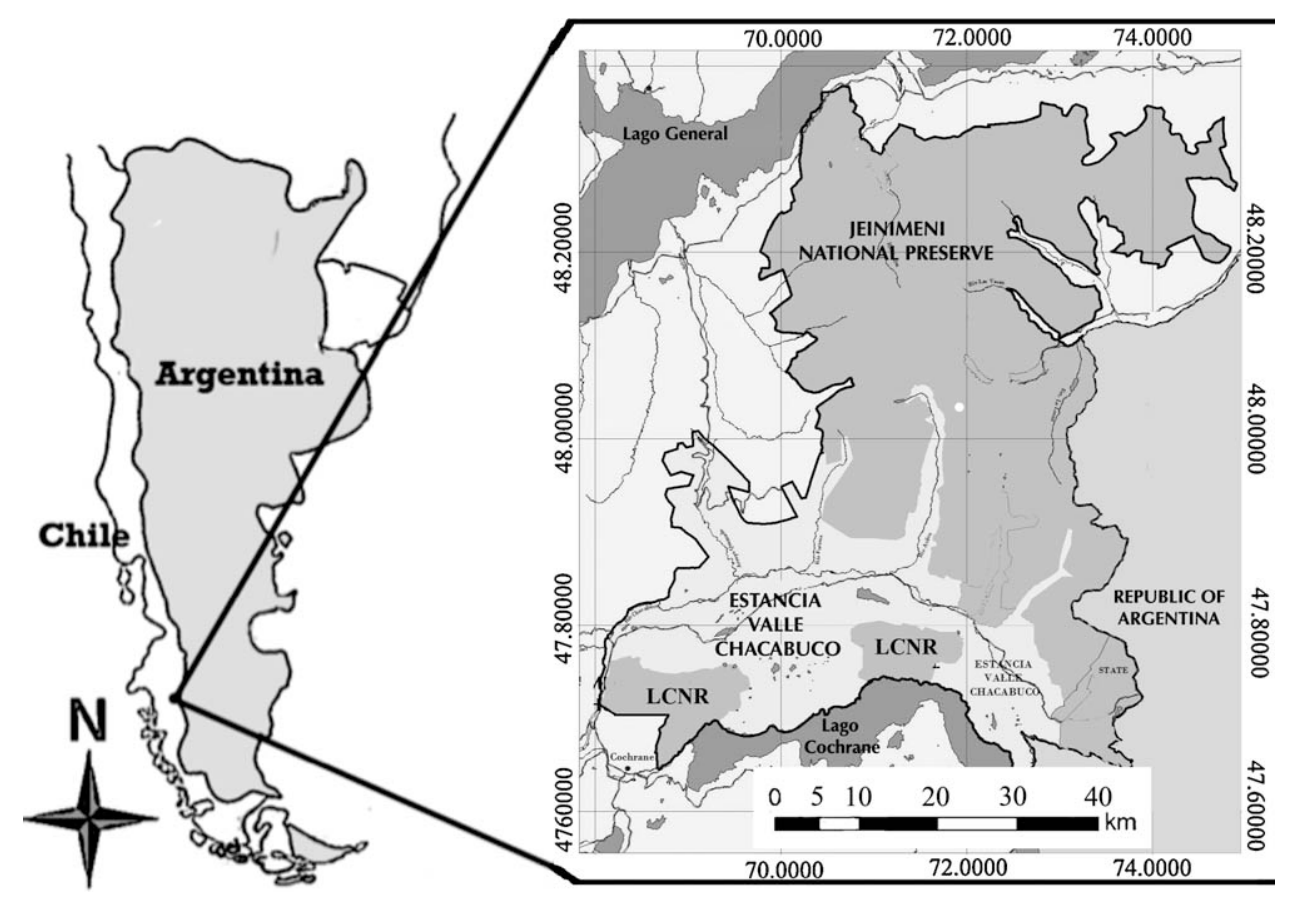

Fig. 1. Location of study area and inset delineating land ownership (LCNR= Lago Cochrane National Reserve).

in Patagonia has been reported (Franklin et al., 1999), and much remains unknown about them in the southernmost portion of their distribution (Walker and Novaro, 2010).

We fitted 11 pumas in Chilean Patagonia with either GPS $(n=9)$ or VHF collars $(n=2)$ at the interface of the open steppe and forested Andean mountains to increase our understanding of the spatial ecology of solitary felids in mixed habitats, including grasslands with primarily aggregating prey. Based on detailed location data, we quantified daily movements and investigated land cover associations (as a coarse descriptor for habitat) for pumas and for puma kill sites. Further, we assessed biologically reasonable covariates (puma age and gender, available prey biomass, land cover type) for their role in determining home range size.

We hypothesized that puma daily movements, preferential habitat use, home range sizes, and density in our study area would be functions of prey distributions (high prey densities and large aggregations) and availability (the guanaco's distribution in steppe habitat) (Logan and Sweanor, 2001; Bank et al., 2003). We hypothesized that, contrary to previous research findings in North America, pumas would exhibit preference for steppe grasslands-inferred from location data and kill sites-because it was in steppe that prey was most abundant, and because in Patagonia, pumas do not compete with other large, terrestrial carnivores. Further, we expected puma kills and location data to be found disproportionately in rugged and rocky mountain steppe habitat rather than flat valley steppe because mountain steppe offered greater cover from which to ambush prey. We also hypothesized that available prey biomass would be the strongest determinant of home range size for all pumas, and like pumas in North America, older pumas would have larger home ranges than younger pumas, and males would have larger home ranges than females (Logan and Sweanor, 2001; Grigione et al., 2002). Other research on solitary felids has shown that felids move shorter daily distances and utilize smaller home ranges when prey densities are high (Schmidt, 2008), thus we hypothesized that the daily distances moved by pumas in Patagonia would be shorter and their home ranges would be smaller than those recorded in North America, because of the higher prey densities in Patagonia (Grigione et al., 2002; Laundré, 2005; Logan and Sweanor, 2010). Finally, we hypothesized that the density of pumas in our study area would be higher than those reported for North America in Quigley and Hornocker (2010) because of higher prey densities.

\section{Material and methods}

\section{Study area}

Our study was conducted in the southern portion of Chile's Aysén District, north of Lago Cochrane in central Chilean Patagonia (W 47.8000, S 72.0000, Fig. 1). The study area covered approximately $1200 \mathrm{~km}^{2}$, and included the $69 \mathrm{~km}^{2}$ Lago Cochrane National Reserve, the $690 \mathrm{~km}^{2}$ private Estancia Valle Chacabuco, and approximately 440 of the $1611 \mathrm{~km}^{2}$ Jeinimeni National Reserve; these 3 properties will be combined into the future Patagonia National Park (http://www.conservacionpatagonica.org/). Elevations throughout the study area varied from 200 to $1500 \mathrm{~m}$ asl. The mean annual temperature for this region of Patagonia is $6.5^{\circ} \mathrm{C}$ (Endlicher, 1991). The annual precipitation averages approximately $800 \mathrm{~mm}$, the majority of which falls during the winter months (May-August) as snow (Wittmer et al., 2010). Land cover was characteristic of rugged Patagonia mountains, and included large areas of mixed Patagonia steppe (expansive grasslands interspersed with islands of shrubs and short forests), riparian systems, wetlands, and southern beech (Nothofagus spp.) forests above $700 \mathrm{~m}$.

\section{Puma captures}

We captured pumas from March to September in 2008 and 2009, when locating them was facilitated by the presence of snow on the ground. When conditions were suitable, we traveled on horseback until fresh puma tracks were found, and used hounds to force pumas to retreat to either a tree or rocky outcrop where we could safely approach the animal. Pumas were anesthetized with Ketamine $(2.5-3.0 \mathrm{mg} / \mathrm{kg}$ ) administered with a dart gun, and then lowered to the ground where they were administered Zalopine $(0.075 \mathrm{mg} / \mathrm{kg})$ by syringe. We recorded gender, age (using tooth condition, Heffelfinger, 1997, or gum line recession, Laundré et al., 2000), weight, and standardized body measurements. We fitted 


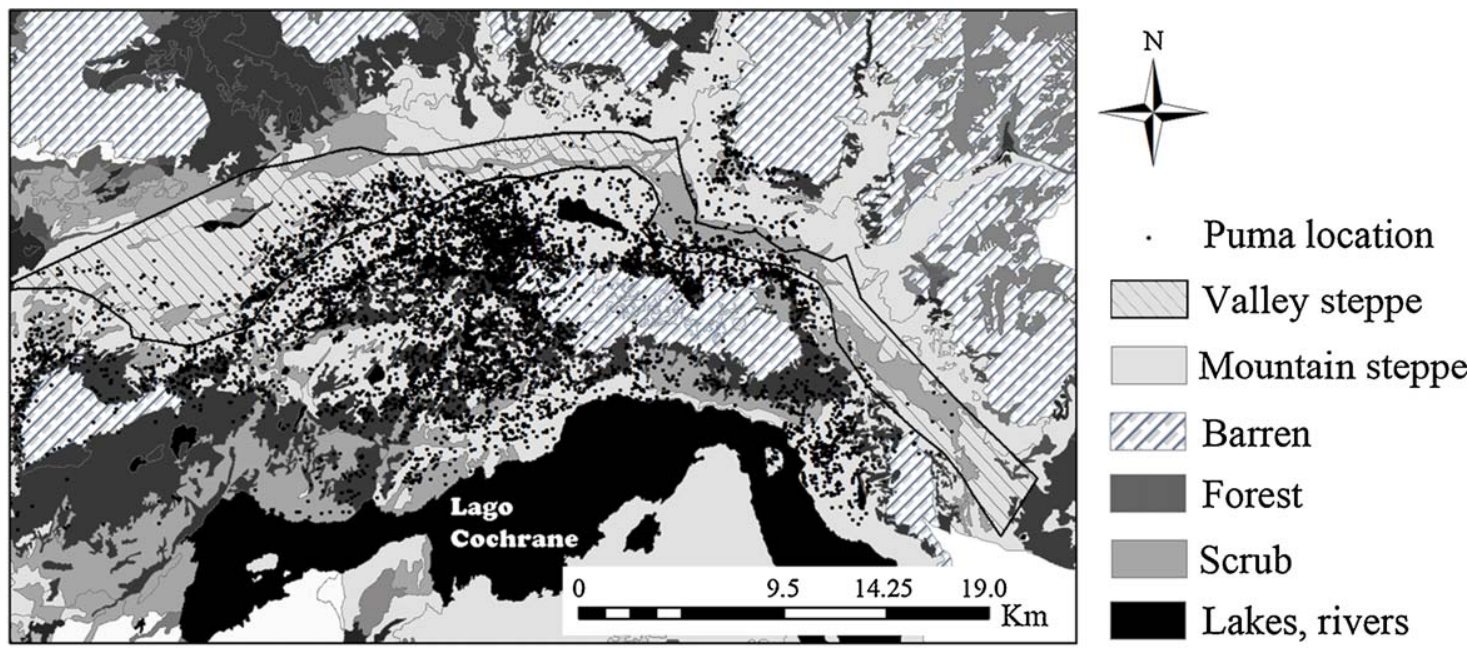

Fig. 2. Puma location data across the 5 land cover classes.

pumas with either an Argos-GPS collar (SirTrack, Televilt, or Lotek) or VHF collar (SirTrack), the weights of which were less than $3 \%$ of adult female weights in the study area, and less than $2 \%$ of the weight of adult males. Once the animal was completely processed, the effects of the capture drugs were reversed with Atipamezole $(0.375 \mathrm{mg} / \mathrm{kg})$, and pumas departed the capture sites on their own.

Although our first puma was a subadult male, we otherwise targeted resident adult pumas. Using track shape and size, we chose to either avoid running females estimated to be less than two years of age or males less than three years, or not to drug and process them if we did, in an attempt not to mark pumas with a higher likelihood of dispersing from the area.

\section{Determining daily distances moved}

Collars were programmed to acquire GPS locations at 2-h intervals, and to transmit data through an Argos uplink at 2-5 day intervals. Our most common programming was a 6-h uplink every 3 days. We measured all distances between consecutive locations gathered by GPS collars using ArcGIS 9.1 (ESRI, Redlands, CA). We quantified daily movements as the summed straight-line distances between sequential GPS locations for each 24 -h period. To avoid underestimating travel distances, we only used days for which there were 8+ GPS points. One collar was programmed to collect location data at 8-h intervals, but was not included in daily distance analyses. Further we walked 10 random trail sections between sequential location data (2-h duration) in light snow cover for 4 pumas ( 3 female, 1 male) to create a correction factor to better estimate daily movements. We recorded the length of puma trails in the field using hand-held GPS units, and quantified the correction factor as the ratio between the trail measured in the field/the direct line distance between the sequential GPS points.

Daily movement data were first tested to see if they followed a normal distribution using a Shapiro-Wilk $W$ test, and Levene's test was used to assess homogeneity of variances (Steel et al., 1997). Because we gathered a variable number of observations per individual puma, we used a mixed-model Analysis of Variance (ANOVA), in which we assigned individual pumas as a random effect, and differences between male and female pumas were assessed with least square means and a probability value of 0.05 (SAS 9.2, Cary, $\mathrm{NC}$ ). We then used a second mixed-model ANOVA to test whether the presence and age of kittens ( 5 categories: none, $0-3$ months old, 3-6 months, 6-12 months, and 12-18 months) were a significant influence on any variability in daily distances traveled by females.

\section{Determining habitat associations for location data and kill sites}

As a first step, we categorized land cover into 5 classes (Fig. 2), defined as follows:

(1) Valley steppe: Flat steppe habitat $200-600 \mathrm{~m}$ in elevation lying along the floor of Valle Chacabuco, and characterized by unobstructed views. Vegetation was open grassland, intermingled with short shrubs, primarily mata barrosa (Mullinum spinosum) and scarlet gorse (Anarthrophyllum desideratum). Common grasses included Stipa speciosa, S. humilis, Poa ligularis, and Bromus pictus. Steppe was also interspersed with small pockets of woody vegetation up to $5 \mathrm{~m}$ tall, including calafate (Berberis microphylla) and ñirre (Nothofagus antarctica).

(2) Mountain steppe: Habitats $600-1200 \mathrm{~m}$ in elevation, characterized by steep slopes, ravines, and rock outcrops providing greater cover for pumas than valley steppe. Vegetation was as described for valley steppe.

(3) Shrubs: Habitats between 200 and $700 \mathrm{~m}$ in elevation, with extensive, very dense woody growth and canopies to $8 \mathrm{~m}$ tall. Woody shrubs varied across the study area, but included ñirre, notro (Embothrium coccineum), and chaura (Pernettya mucronata).

(4) Forests: Habitats between 700 and $1200 \mathrm{~m}$ in elevation, with high canopies $>12 \mathrm{~m}$ tall. Forests were dominated by lenga (Nothofagus pumilio).

(5) Barren mountaintops: Habitats above $1200 \mathrm{~m}$ in elevation, with limited vegetation $<6 \mathrm{~cm}$ tall.

In ArcGIS, we created circular, 10-m radius buffers around each GPS point (collars record location with 5-10 m accuracy) and quantified land cover within these buffers as proportions (e.g., 0.7 steppe, 0.3 forest). Using Hawth's Tools in ArcGIS, we created a Minimum Convex Polygon (MCP) (Mohr, 1947) using locations from all pumas within Chile (i.e., excluding locations from one puma that dispersed to Argentina (Elbroch et al., 2009), and a second puma that spent minimal time on an Argentinean sheep ranch), which we then defined as the delineated study area for population-scale analyses. Then we quantified the surface area of each of the 5 land cover classes within this polygon. We subtracted all open water sources, even though one individual was known to cross aquatic habitats for foraging purposes (Elbroch et al., 2010). First we used a chi-square test of independence and likelihood ratios to determine whether the summed land cover counts for the location data of individual pumas and the distribution of GPS data in the five cover classes 
were independent of each other, and to test whether second-order or third-order habitat selection (Johnson, 1980) was an appropriate measure in our system (Dasgupta and Alldredge, 2000; Fieberg et al., 2010). Then, we used chi-square goodness of fit tests to assess second-order habitat selection, in which we determined whether land covers used by all pumas (as determined within buffers) were distributed across cover classes in proportion to their availability in the entire study area, and third-order habitat selection (Johnson, 1980), in which we determined whether each individual puma's location data were distributed across cover classes in proportion to the availability of these habitats within their respective home ranges.

We analyzed the locations of puma kill sites by the same process as for second-order habitat selection of puma locations, applying a $10-\mathrm{m}$ radius buffer around each point to account for potential GPS error in our handheld units. For ungulates killed, we defined the center of the site as the location of the rumen. For European hares (Lepus europaeus), the kill site was defined by the location of the stomach or intestines when they were available, or the largest collection of any remains. We used a chi-square goodness of fit test to test whether kill sites were distributed in proportion to the distribution of prey densities calculated within each available land cover type (see below).

\section{Quantifying prey densities and biomass}

We estimated densities of guanacos in the different land cover types in 2010 using distance sampling (Thomas et al., 2010). Transect widths were limited by range finder technology to $800 \mathrm{~m}$ wide in valley steppe, and to $200 \mathrm{~m}$ wide by landscape contours in mountain steppe. Shrubs and forests, in which visibility was limited to $50-100 \mathrm{~m}$ wide transects, were combined into one cover class due to the similarities in detection probabilities in these habitats.

Two observers walked 60 randomly selected $1-\mathrm{km}$ transects distributed across the 3 major cover class types on the estancia in June 2010: (a) valley steppe, (b) mountain steppe, and (c) shrub-forest. Habitat-specific densities for guanacos were then estimated using program Distance 6.0 (Thomas et al., 2010). The number of resident guanacos in the surrounding national reserves was negligible, totaling approximately 50 individuals (Torres, 1992).

We also estimated abundances for European hares, sheep, and huemul (Hippocamelus bisulcus). Distance sampling was used to estimate European hare densities in winter 2010. Eighty kilometers of roads were driven at night and searched with spotlights ( $80 \mathrm{~m}$ wide transects). Habitat-specific hare densities were estimated for steppe (combined valley and mountain steppes because detection distances were shorter than for guanacos and unaffected by terrain), and shrub-forest cover classes using program Distance 6.0. Sheep in the study area were counted in January of each year, and we used the huemul population estimate of 120 individuals reported by Corti et al. (2011).

Using known prey locations for sheep and huemul, and cover class-specific densities for guanacos and hares, we quantified prey biomass in each puma's 95\% kernel home range in terms of $\mathrm{kg}$ of prey. We used adult weights for all animals, except guanacos. During transect sampling for guanacos, the percent of first-year animals among mixed groups was also recorded (18.9\%) and we multiplied this proportion by the weight of 6 -month old guanacos $(27.3 \mathrm{~kg})$ to more realistically reflect actual biomass on the landscape. For sheep, we used adult weights because nearly all the lambs were sold off each Christmas at approximately 2 months of age. We used adult huemul weights of $65 \mathrm{~kg}$ (Iriarte, 2008), $4 \mathrm{~kg}$ for European hares (the mean weight of 30 specimens hunted by locals or killed by vehicles), $40 \mathrm{~kg}$ for adult sheep (mean weight of slaughtered sheep), and $120 \mathrm{~kg}$ for adult guanacos (Raedeke, 1979).

\section{Quantifying home ranges and home range overlap}

Home ranges were estimated for pumas with GPS data using 2 methods. First, 100\% of the data were used to create cumulative MCPs by month in ArcGIS, using the Hawth's Tools extension (Beyer, 2004), to allow for comparisons with previous home range estimates for pumas in Patagonia and elsewhere (Franklin et al., 1999). Secondly, we filtered data to estimate 95\% home ranges using a fixed kernel estimator (Worton, 1989) and least square cross validation (LSCV) to determine the smoothing factor h (Seaman and Powell, 1996). To minimize temporal autocorrelation, only GPS points taken at $12 \mathrm{am}, 8 \mathrm{am}$, and $4 \mathrm{pm}$ were included; systematic sampling maintained a randomized design (Kie et al., 2010). Then we used assessed spatial autocorrelation in our data using Moran's I statistic. LSCVs and the 95\% kernel home ranges were calculated in ArcView 3.2, using the Animal Movement Extension (Hooge and Eichenlaub, 1997).

We used multiple regression analyses to test variables that might explain fixed kernel home range size for the 9 pumas with GPS collars. We considered the following 7 covariates: (1) prey biomass per home range (total $\mathrm{kg}$ of guanaco, sheep, hare, and huemul, see methods above), (2) puma weight, (3) puma age, (4) puma gender, (5) duration of monitoring (number of months of data used to calculate home ranges), (6) amount of valley steppe $\left(\mathrm{km}^{2}\right.$ of valley steppe land cover in their respective kernel home ranges) and (7) amount of mountain steppe in their respective home ranges. To account for low sample sizes we attempted to reduce the number of covariates. First, we used pairwise coefficient correlations, and a correlation cut off of 0.5 , to test for significant correlation between independent variables. When two or more variables were significantly correlated, we selected the variable with the highest correlation with home range size to be included in the final analysis. In the end, three variables remained to run a full model multiple regression.

Fixed kernel home range overlap between marked pumas was calculated using the polygon overlap analysis tools in Hawth's Tools in ArcGIS 9.1. Overlap was quantified as a percentage of a puma's 95\% kernel home ranges.

Location data were collected opportunistically for the 2 pumas fitted with VHF collars. The original purpose of VHF collars was to mark pumas while snows allowed us to use tracks to locate new pumas, and then regardless of snow cover, to facilitate easier capture scenarios of the same pumas when an Argos-GPS collar became available; only later was it decided they might also contribute to analyses. Location data were documented 3-10 times per month for these individuals. We estimated MCPs for the 2 pumas wearing VHF collars using $100 \%$ of their location data and used these values in our calculations to estimate puma densities (see below).

\section{Quantifying puma density}

Because our capture effort was uneven across the study area, we employed a density estimate for 2009 using overlapping home ranges to calculate pumas $/ 100 \mathrm{~km}^{2}$ (McLellan, 1989; Cooley et al., 2009). First, we determined the boundaries of the area in which we searched for pumas repeatedly through the winter of 2009, and where we were certain we had collared all resident pumas (we never encountered any puma tracks that could not be accounted for by collared animals). Following Cooley et al. (2009), we combined the location data for all the resident females that remained completely within the area where we searched for pumas most frequently in ArcGIS 9.1 and created a single MCP for their combined data. Then, we summed the proportion of each additional overlapping pumas' MCPs (quantified as a fraction and determined using Hawth's Tools and ArcGIS 9.1) with the combined MCP of the resident females to determine a number of resident pumas for the 
Table 1

Gender, age, weight, collar type, and length of monitoring of captured pumas.

\begin{tabular}{|c|c|c|c|c|c|c|c|}
\hline ID & Gender & Age (years) & Weight (kg) & Collar type & $\begin{array}{l}\text { Length of } \\
\text { monitoring (days) }\end{array}$ & $\begin{array}{l}\text { 95\% kernel home range } \\
\text { in } \mathrm{km}^{2} \text { (number of } \\
\text { locations used) }\end{array}$ & $\begin{array}{l}100 \% \mathrm{MCP} \text { home range } \\
\text { in } \mathrm{km}^{2} \text { (number of } \\
\text { locations used) }\end{array}$ \\
\hline M1 & M & $2.5^{\mathrm{a}}$ & 72 & Argos GPS (SirTrack) & 110 & $183(64)$ & $206(265)$ \\
\hline M2 & M & $5^{\mathrm{b}}$ & 73.5 & $\begin{array}{l}\text { Argos GPS } \\
\text { (SirTrack)/Argos GPS } \\
\text { (Lotek) }\end{array}$ & 453 & $370(607)$ & $488(2268)$ \\
\hline M3 & M & $6^{\mathrm{b}}$ & 66 & Argos GPS (Lotek) & 351 & $149(754)$ & $289(3033)$ \\
\hline M4 & M & $8^{\mathrm{b}}$ & 82 & Argos GPS (Lotek) & 245 & $114(461)$ & $240(937)$ \\
\hline $\mathrm{F} 1$ & $\mathrm{~F}$ & $2.5^{\mathrm{a}}$ & 35 & Argos GPS (Telonics) & 211 & 53 (599) & $96(599)$ \\
\hline $\mathrm{F} 2$ & $\mathrm{~F}$ & $2.5^{\mathrm{a}}$ & 32 & Argos GPS (SirTrack) & 91 & $83(85)$ & $90(314)$ \\
\hline F3 & $\mathrm{F}$ & $3.5^{\mathrm{b}}$ & 38 & Argos GPS (Lotek) & 534 & $121(772)$ & $222(3267)$ \\
\hline $\mathrm{F} 4$ & $\mathrm{~F}$ & $4^{\mathrm{b}}$ & 36 & Argos GPS (Lotek) & 453 & $98(1092)$ & $251(4422)$ \\
\hline F5 & $\mathrm{F}$ & $2^{\mathrm{b}}$ & 38 & Argos GPS (Lotek) & 237 & $120(447)$ & $179(1788)$ \\
\hline F6 & $\mathrm{F}$ & $1.5^{\mathrm{b}}$ & 30 & VHF & 191 & - & $91(53)$ \\
\hline F7 & $\mathrm{F}$ & $2.5^{\mathrm{a}}$ & 32.5 & VHF & 162 & - & $112(46)$ \\
\hline
\end{tabular}

a Heffelfinger (1997).

b Laundré et al. (2000).

area delineated by the MCP for the combined female data. This calculation included the MCPs for the 2 pumas wearing VHF collars. Finally, we scaled this calculation to pumas $/ 100 \mathrm{~km}^{2}$. In addition, we used the numbers of kittens for collared females over the same area, determined and rechecked repeatedly during captures, direct observations, by tracks in snow and/or remote cameras at kill sites, to calculate a second density of all known pumas in the same area.

\section{Results}

Captures

We captured 11 pumas ( 4 males and 7 females) in 2008-09 and fitted them with either GPS $(n=9)$ or VHF $(n=2)$ collars (Table 1$)$. Pumas were monitored from May 2008 through December 2010. GPS data were collected for pumas for a mean of $9.33 \pm 5.66$ months. F6 was a mature kitten still traveling with her mother and male sibling for the duration of her monitoring period.

\section{Daily distances}

Mean daily distances traveled were not significantly different for males and females (LS means $8.82 \pm 1.50 \mathrm{~km}$ compared with $7.45 \pm 1.49 \mathrm{~km}$ respectively; $\left.F_{1,5.51}=0.42, P=0.5415\right)$. The correction factor for 10 trails made between sequential location data was $1.64 \pm 0.48$. Multiplying by the correction factor, pumas on average moved $13.42 \pm 2.50 \mathrm{~km}$ per day. The presence and age of kittens also proved not to be a significant influence on daily distances $\left(F_{4,4.68}=0.50, P=0.7405\right)$. The longest daily distance (sum of straight lines between sequential GPS points without correction) recorded during our study was $53 \mathrm{~km}$ made by a female with yearling kittens.

\section{Habitat associations for puma locations and kill sites}

Using a total of 16,012 locations, we defined the study area (for population scale quantitative analyses) as a $1062 \mathrm{~km}^{2} \mathrm{MCP}$. We rejected the null hypothesis for the chi square test of independence $\left(\chi_{32}^{2}=1886.530, P<0.0001\right)$ and concluded that due to the high variation in resource selection among individual pumas, an assessment of second order habitat selection by pumas was inappropriate for this study system.

Within their home ranges (third-order selection), pumas used forested habitats more than expected, and barren mountaintops less than expected, assuming random movements (Table 2). The location data for 7 of 9 pumas were located in steppe habitat most often, yet only 4 of 9 pumas were located within valley steppe, and 2 of 9 pumas in mountain steppe, more than expected given their availabilities within each pumas' respective home ranges (Table 2 ).

The locations of guanaco $(n=332)$, sheep $(n=41)$ and hare $(n=73)$ kill sites were distributed disproportionately across cover classes with respect to their availability and their relative prey densities (Table 3). Guanaco kills were disproportionately found

Table 2

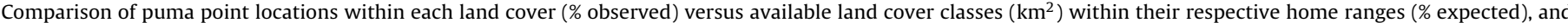
results of chi-square tests.

\begin{tabular}{|c|c|c|c|c|c|c|c|c|c|c|}
\hline Habitat & Puma All pumas & M1 & M2 & M3 & M4 & $\mathrm{F} 1$ & $\mathrm{~F} 2$ & F3 & $\mathrm{F} 4$ & F5 \\
\hline \multicolumn{11}{|l|}{ Valley steppe } \\
\hline Observed & $9.8 \%$ & $23.9 \%$ & $8.6 \%$ & $2.7 \%$ & $7.0 \%$ & $0.9 \%$ & $8.4 \%$ & $36.6 \%$ & $2.6 \%$ & $0.0 \%$ \\
\hline Expected & $7.2 \%$ & $18.6 \%$ & $10.8 \%$ & $6.9 \%$ & $1.3 \%$ & $10.5 \%$ & $5.2 \%$ & $22.5 \%$ & $4.6 \%$ & $0.0 \%$ \\
\hline \multicolumn{11}{|l|}{ Mountain steppe } \\
\hline Observed & $44.2 \%$ & $38.0 \%$ & $46.3 \%$ & $58.5 \%$ & $56.9 \%$ & $65.0 \%$ & $52.8 \%$ & $33.1 \%$ & $35.7 \%$ & $45.5 \%$ \\
\hline Expected & $46.0 \%$ & $31.2 \%$ & $61.3 \%$ & $64.1 \%$ & $72.8 \%$ & $71.5 \%$ & $49.6 \%$ & $66.4 \%$ & $58.0 \%$ & $58.1 \%$ \\
\hline \multicolumn{11}{|l|}{ Shrubs } \\
\hline Observed & $9.1 \%$ & $7.6 \%$ & $6.1 \%$ & $8.3 \%$ & $10.0 \%$ & $0.9 \%$ & $13.3 \%$ & $6.9 \%$ & $14.3 \%$ & $5.2 \%$ \\
\hline Expected & $3.9 \%$ & $2.0 \%$ & $6.5 \%$ & $2.1 \%$ & $1.1 \%$ & $0.1 \%$ & $26.2 \%$ & $5.9 \%$ & $0.9 \%$ & $2.7 \%$ \\
\hline \multicolumn{11}{|l|}{ Forest } \\
\hline Observed & $31.8 \%$ & $7.6 \%$ & $34.1 \%$ & $23.3 \%$ & $22.0 \%$ & $13.8 \%$ & $24.1 \%$ & $21.6 \%$ & $41.5 \%$ & $49.0 \%$ \\
\hline Expected & $4.4 \%$ & $6.1 \%$ & $6.5 \%$ & $2.9 \%$ & $5.3 \%$ & $13.6 \%$ & $13.3 \%$ & $3.2 \%$ & $19.7 \%$ & $25.4 \%$ \\
\hline \multicolumn{11}{|l|}{ Barren } \\
\hline Observed & $5.2 \%$ & $22.8 \%$ & $5.0 \%$ & $7.3 \%$ & $4.1 \%$ & $19.5 \%$ & $1.4 \%$ & $1.8 \%$ & $5.9 \%$ & $0.3 \%$ \\
\hline Expected & $38.4 \%$ & $42.0 \%$ & $14.9 \%$ & $24.0 \%$ & $19.5 \%$ & $4.3 \%$ & $5.8 \%$ & $2.0 \%$ & $16.8 \%$ & $13.8 \%$ \\
\hline Number of point locations & 16,012 & 115 & 1369 & 2987 & 540 & 733 & 358 & 2836 & 1788 & 4362 \\
\hline$\chi_{4}^{2}$ & 18148.42 & 20.9432 & 1065.033 & 2584.331 & 485.1745 & 270.7981 & 61.6076 & 2091.068 & 3951.543 & 764.4925 \\
\hline$P$ & $<0.0001$ & 0.0003 & $<0.0001$ & $<0.0001$ & $<0.0001$ & $<0.0001$ & $<0.0001$ & $<0.0001$ & $<0.0001$ & $<0.0001$ \\
\hline
\end{tabular}


Table 3

Comparison of kill site point locations within each land cover (\% observed) with available land cover classes in the study area in terms of $\mathrm{km}^{2}$ (\% expected), and results of chi-square tests.

\begin{tabular}{lccc}
\hline Habitat & Hares & Guanacos & Sheep \\
\hline Valley steppe & & & \\
Observed & $4 \%$ & $26 \%$ & $71 \%$ \\
$\quad$ Expected & $7 \%$ & $19 \%$ & $96 \%$ \\
Mountain steppe & & & \\
$\quad$ Observed & $39 \%$ & $48 \%$ & $12 \%$ \\
$\quad$ Expected & $71 \%$ & $66 \%$ & $1 \%$ \\
Shrubs & & & \\
Observed & $11 \%$ & $4 \%$ & $0 \%$ \\
Expected & $13 \%$ & $5 \%$ & $1 \%$ \\
Forest & & & \\
Observed & $43 \%$ & $18 \%$ & $17 \%$ \\
Expected & $4 \%$ & $5 \%$ & $1 \%$ \\
Barren & & & \\
$\quad$ Observed & $3 \%$ & $5 \%$ & $1 \%$ \\
Expected & $5 \%$ & 332 & 41 \\
Number of kill sites & 73 & 93.4384 & 47.0191 \\
$\chi_{4}^{2}$ & 105.6378 & $<0.0001$ & $<0.0001$ \\
$P$ & $<0.0001$ & & \\
\hline
\end{tabular}

in valley steppe, but found less than expected in mountain steppe. Hare kills were located less often than expected in valley and mountain steppe habitats, and both guanaco and hare kills were found in forests significantly more than expected, given both the relatively lower prey availability in forests and the limited distribution of forests in the study area. The 7 sheep killed in shrub habitat and the 5 sheep killed in mountain steppe had escaped their enclosures, which were entirely in valley steppe habitat. As expected, all huemul kills $(n=7)$ were found in forested habitats.

\section{Prey densities}

Guanaco densities were highest in valley steppe habitat $(\bar{X}=$ $\left.71.3 / \mathrm{km}^{2}, 95 \% \mathrm{CI}=33.5-151.6\right)$ followed by mountain steppe habitat $\left(\bar{X}=34.4 / \mathrm{km}^{2}, 95 \% \mathrm{CI}=13.2-89.9\right)$. Guanacos were not detected in shrub-forest habitats or in $153 \mathrm{~km}^{2}$ of steppe habitat in the east and northeast of the study area, where sheep ranching was the dominant activity. Hare densities averaged $42.5 / \mathrm{km}^{2}$ (95\% CI 20.3-89.3) in both steppe habitats (pooled across valley and mountain steppe) and forests, and $89.0 / \mathrm{km}^{2}(95 \% \mathrm{CI}=44.3-179.1)$ in shrub habitats. Ranchers counted 2500 sheep in the eastern portion of the study area in 2009-10. In sum, we calculated that there were $6550(95 \% \mathrm{CI}=3316-17,629)$ guanacos, 21,973 hares $(95 \%$ $\mathrm{CI}=13,078-45,916), 120$ huemul, and 2500 sheep in our $1062 \mathrm{~km}^{2}$ study area. We also calculated that steppe habitat composed 53\% of the study area, and contained $98 \%$ of the available prey biomass.

\section{Home ranges and home range overlap}

Disregarding 2 pumas for which we had less than 3 months of data, $95 \%$ fixed kernel home ranges averaged $98 \pm 31.8 \mathrm{~km}^{2}$ for females and $211 \pm 138.8 \mathrm{~km}^{2}$ for males (Table 1). Cumulative MCP home ranges are found in Fig. 3. We only have one month of usable data for M1 who dispersed from our study area and was killed (Elbroch et al., 2009).

Correlation coefficients between prey biomass, amount of valley steppe, and amount of mountain steppe land covers were greater than 0.5 . Prey biomass proved the most strongly correlated with home range size, and was thus retained for the model. Correlation coefficients between puma weight, gender and age were also greater than 0.5 , and puma weight was retained for the model. The final model was run with three covariates: duration of monitoring, puma weight, and prey biomass. The model was strong and significant $\left(R^{2}=0.82, F_{3,8}=7.52, P=0.0267\right)$.

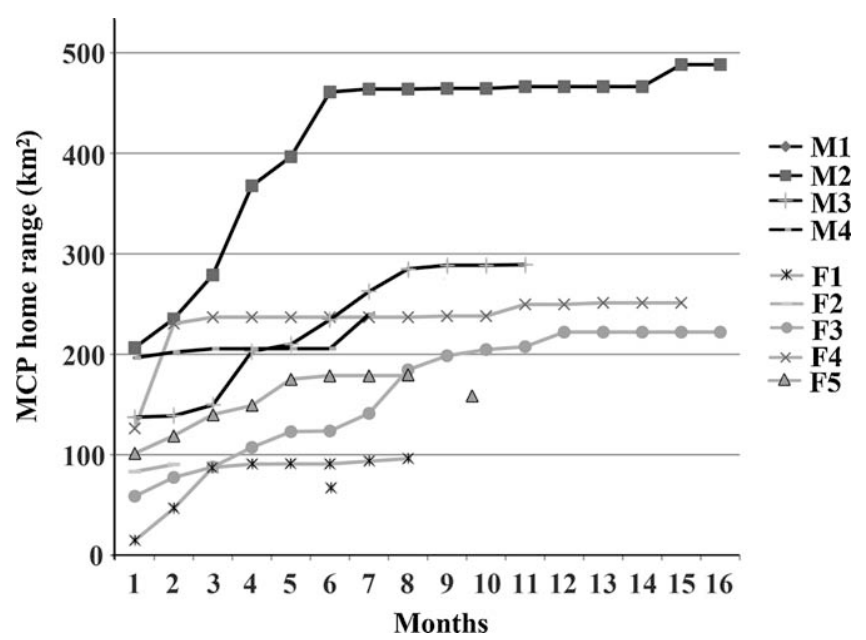

Fig. 3. MCP home ranges over time.

Home range overlap was substantial $(60 \% \pm 14.4 \%)$ for four females wearing GPS collars in the area where we believed we had collared all females. Forty-three percent of F1's kernel home range, 58\% of F3's, 78\% of F4's, and 61\% of F5's overlapped with other marked females (Fig. 4). M2 and M3 shared $27.5 \mathrm{~km}^{2}$ (Fig. 4), which was $7 \%$ of M2's home range and $18 \%$ of M3's. M3 shared an additional $4 \%$ of his range with $\mathrm{M} 4$, for a total of $22 \%$ home range overlap with other marked males.

\section{Puma density}

Location data for 4 adult females fell within the area where we searched for pumas most frequently, and their combined location data created a $450 \mathrm{~km}^{2}$ MCP. F6 (VHF collar) was monitored for 6 months and we calculated a $91 \mathrm{~km}^{2}$ MCP using 100\% of her location data $(n=53)$. F7 (VHF collar) was monitored 5 months and we calculated a $112 \mathrm{~km}^{2}$ MCP using $100 \%$ of her location data $(n=46)$. We overlapped portions of 5 additional MCPs of marked pumas with the MCP of the 4 females, to calculate a total of 6.08 pumas $/ 450 \mathrm{~km}^{2}\left(1.35 / 100 \mathrm{~km}^{2}\right)$. There were 1.04 females $/ 100 \mathrm{~km}^{2}$ and 0.31 males $/ 100 \mathrm{~km}^{2}$. When we included

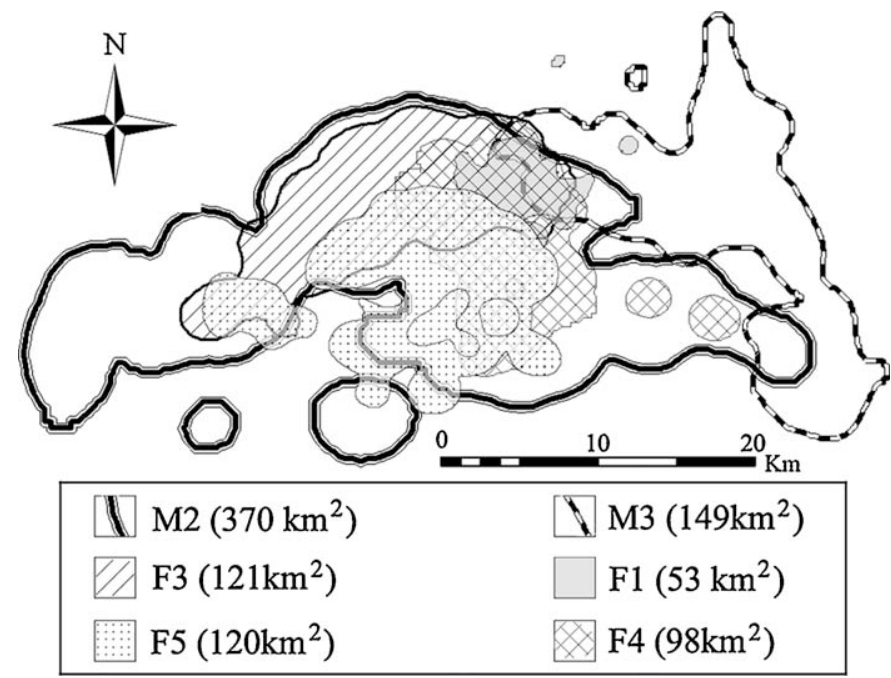

Fig. 4. Overlapping 95\% fixed kernel home ranges of 6 pumas. The empty shapes with thick borders are Males M2 $\left(370 \mathrm{~km}^{2}\right)$ and M3 $\left(149 \mathrm{~km}^{2}\right)$, and the interior, smaller shapes with 4 different textures are overlapping females $\mathrm{F} 1\left(96 \mathrm{~km}^{2}\right), \mathrm{F} 3$ $\left(121 \mathrm{~km}^{2}\right), \mathrm{F} 4\left(98 \mathrm{~km}^{2}\right)$, and F5 $\left(120 \mathrm{~km}^{2}\right)$. 
known kittens in our calculations puma densities were estimated as 15.48 pumas $/ 450 \mathrm{~km}^{2}\left(3.44 / 100 \mathrm{~km}^{2}\right)$.

\section{Discussion}

We found support for many of our predictions about the spatial ecology of pumas in open habitats with aggregate prey and without large, terrestrial competitors. Seven of 9 pumas in our study were most often located in open steppe habitat, 2 of 9 pumas showed preferential selection for mountain steppe, and 4 of 9 pumas showed preference for valley steppe, where guanaco densities were highest. Puma kill sites were also most often located in steppe habitat, and guanaco kills were located in valley steppe much more than expected given the small distribution of valley steppe and its prey densities. However, like pumas in North America (Williams et al., 1995; Dickson and Beier, 2002; Ernest et al., 2003), more individual pumas in our study exhibited avoidance of grassland habitats than did preference (Table 2). Whereas pumas in our study most often hunted in steppe grasslands, especially guanacos in valley steppe, they otherwise avoided grasslands for other aspects of their lives.

We did not find support for our prediction that puma kills would be located in mountain steppe more than expected, due to the increased cover mountain steppe provided hunting pumas. Instead, pumas selected for areas with higher guanacos densities over areas with lower densities but increased ambush terrain. Puma location data and kill sites were also found in forests in much greater abundance than expected given either the availability of forests or our estimated prey biomass in forests. Similarly, Franklin et al. (1999) reported that pumas in Torres del Paine NP utilized forested habitats more than any other habitat. Guanaco sign was evident in forests, in the form of runs, tracks, and scats, yet guanacos appeared to use forests primarily while traversing between steppe habitats. Pumas, therefore, likely attacked guanacos while they were traveling through forests, and made more vulnerable due to the structural cover provided pumas.

We found support for our hypothesis that pumas in Patagonia would move shorter distances than have been recorded in North America. Our uncorrected estimates of daily distances traveled by pumas were $50 \%$ shorter than the $16.1 \mathrm{~km} /$ day reported in Laundré (2005), and suggest that high prey densities and large aggregations were an important variable influencing observed daily travel distances. Like Laundré (2005), we did not find differences in daily movements between females and males, nor among females with and without kittens. Contrary to the daily distances, we did not find support for our prediction that pumas should utilize smaller home ranges in areas of high prey densities. While our home range calculations (MCPs) were larger than those reported for southernmost Patagonia (98 vs. $69 \mathrm{~km}^{2}$ for females and 211 vs. $39 \mathrm{~km}^{2}$ for males; Franklin et al., 1999), they were equivalent to those reported for North America (Grigione et al., 2002; Logan and Sweanor, 2010).

Prey biomass best explained variation in puma home ranges. Many different factors have been shown to influence variation in home range size in felids (e.g., reproductive status and body mass in Grigione et al., 2002), and in our analysis, prey biomass, puma weight and the duration a puma was monitored explained $82 \%$ of the variation among home ranges of pumas in our study. In North America, female puma home ranges overlap 40-60\% with other females (Logan and Sweanor, 2010), similar to what we calculated in Patagonia. Males in North America also overlap with each other, although they tend to use the overlapping portions of their home ranges at different times (Logan and Sweanor, 2010). The limited number of marked adult male pumas in our study limited our ability to assess male-male overlap.
We were surprised that we did not find support for our hypothesis that puma densities would be higher in our study area due to higher prey densities than those reported for North America (from 0.6 to 3.9 total pumas/100 $\mathrm{km}^{2}$ for 7 studies; Quigley and Hornocker, 2010). Quigley and Hornocker (2010), however, cautioned against comparing puma density estimates across study areas too closely because of the disparate methods currently employed, and there is limited research making direct comparisons between puma densities and known local prey densities. Using methods comparable to those applied here, Cooley et al. (2009) reported similar values to ours (3.33 total pumas $/ 100 \mathrm{~km}^{2}$ as compared with our $3.44 / 100 \mathrm{~km}^{2}$ ). Our density estimates were much lower than those determined through "direct counts" for Torres del Paine National Park (30 pumas/100 km² in Franklin et al., 1999). Our estimates were more than four times that reported for northern Argentina $\left(0.67 \pm 0.16\right.$ total pumas $\left./ 100 \mathrm{~km}^{2}\right)$, as determined with camera traps (Kelly et al., 2008).

Our research suggests that pumas are not structurally complex habitat specialists and will use open habitats with aggregating prey in the absence of large, terrestrial competitors. Pumas in our study preferentially hunted guanacos in flat, open grasslands where they were most abundant, and closed canopy forests, where they were most vulnerable to ambush. Thus, our research supports the notion that wolves and bears may limit pumas to structurally complex habitats in North America (Riley et al., 2004; Ruth and Murphy, 2010). Unlike social felids that benefit from group defense of their kills (e.g., African lions, Panthera leo, Mosser and Packer, 2009), solitary pumas that share open habitats with large competitive scavengers in North America must retreat to cover and attempt to remain unobtrusive to minimize conflicts with other carnivores (Ruth and Murphy, 2010). Unlike pumas in North America, Patagonia pumas in our study were primarily located in open habitats in which ungulate prey aggregated in large groups. However, Patagonia pumas also exhibited behaviors similar to their northern counterparts and preferentially selected for habitat with complex structure for use as secure retreats and to aid in the stalking and ambushing of their prey.

\section{Acknowledgements}

Funding for this work was generously provided by the National Science Foundation (USA), National Geographic Society, Conservación Patagonica, Felidae Conservation Fund, Oregon Zoo Future for Wildlife Program, Pacific Rim Research Program, University of California, Davis, the Hemispheric Institute on the Americas, The American Society of Mammalogy Grants in Aid of Research Program, and the Stockton Sportsman's Club. All field methods were reviewed and approved by SAG (Chile Agricultural and Cattle Service) and an independent Institutional Animal Care and Use Committee at the University of California, Davis (Protocol \# 13252). We are thankful to our entire puma capture team, particularly Arcilio Sepúlveda, Luigi David Solis, Cristián Rivera, Boone Smith, Cristián Saucedo, and Kris Tompkins. Thank you to M. Santos and D. Kelt for feedback on an earlier version of the manuscript, and to D. Miquelle and W. Franklin for refining our message in later versions.

\section{References}

Bank, M.S., Sarno, R.J., Franklin, W.L., 2003. Spatial distribution of guanaco mating sites in southern Chile: conservation implications. Biol. Conserv. 112, 427-434. Beier, P., 2010. A focal species for conservation planning. In: Hornocker, M., Negri, S. (Eds.), Cougar: Ecology and Conservation. University of Chicago Press, Chicago, pp. 177-190.

Beyer, H.L., 2004. Hawth's analysis tools for ArcGIS. http://www.spatialecology. com/htools.

Cooley, H.S., Wielgus, R.B., Koehler, G.M., Maletzke, B.T., 2009. Source populations in carnivore management: cougar demography and emigration in a lightly hunted population. Anim. Conserv. 12, 321-328. 
Corti, P., Shafer, A.B., Coltman, D.W., Festa-Bianchet, M., 2011. Past bottlenecks and current population fragmentation of endangered huemul deer (Hippocamelus bisulcus): implications for preservation of genetic diversity. Conserv. Genet. 12, 119-128.

Dasgupta, N., Alldredge, J.R., 2000. A chi-square goodness-of-fit analysis of dependent resource selection data. Biometrics 56, 402-408.

Dickson, B.G., Beier, P., 2002. Home range and habitat selection by adult cougars in southern California. J. Wildlife Manage. 66, 1235-1245.

Elbroch, M., Wittmer, H.U., Saucedo, C., 2010. Swimming by pumas (Puma concolor) in Patagonia: rethinking barriers to puma movement. Stud. Neotrop. Fauna Environ. 45, 187-190.

Elbroch, M., Wittmer, H.U., Saucedo, C., Corti, P., 2009. Long-distance dispersal of a Patagonia puma. Rev. Chil. Hist. Nat. 82, 459-461.

Endlicher, W., 1991. Zur klimageographie und klimaökologie von südpatagonien. 100 jahre klimatologische messungen in Punta Arenas. Freiburger Geographische Hefte 32, 181-211.

Ernest, H.B., Boyce, W.M., Bleich, V.C., May, B., Stiver, S.J., Torres, S.G., 2003. Genetic structure of mountain lion (Puma concolor) populations in California. Conserv. Genet. 4, 353-366

Fieberg, J., Matthiopoulos, J., Hebblewhite, M., Boyce, M.S., Frair, J.L., 2010. Correlation and studies of habitat selection: problem, red herring or opportunity? Philos. T. R. Soc. B 365, 2233-2244.

Franklin, W.L., Johnson, W.E., Sarno, R.J., Iriarte, J.A., 1999. Ecology of the Patagonia puma in southern Chile. Biol. Conserv. 90, 33-40.

Grigione, M.M., Beier, P., Hopkins, R.A., Neal, D., Padley, W.D., Schonewald, C.M. Johnson, M.L., 2002. Ecological and allometric determinants of home-range size for mountain lions (Puma concolor). Anim. Conserv. 5, 317-324.

Hayward, M.W., Henschel, P., O’Brien, J., Hofmeyr, M., Balme, G., Kerley, G.I., 2006. Prey preferences of the leopard (Panthera pardus). J. Zool. 270, 298313.

Heffelfinger, J., 1997. Age Criteria for Arizona Game Species, Special Report \#19. Arizona Game and Fish Department, Phoenix.

Hooge, P.N., Eichenlaub, B., 1997. Animal Movement Extension to Arcview. ver. 1.1. Alaska Science Center - Biological Science Office, U.S. Geological Survey, Anchorage, AK, USA.

Iriarte, A., 2008. Mammiferos de Chile. Lynx Editions, Barcelona.

Johnson, D.H., 1980. The comparison of usage and availability measurements for evaluating resource preference. Ecology 61, 65-71.

Kelly, M.J., Noss, A.J., Di Bitetti, M.S., Maffei, L., Arispe, R.L., Paviolo, A., De Angelo, C.D., Di Blanco, Y.E., 2008. Estimating puma densities from camera trapping across three study sites: Bolivia, Argentina, and Belize. J. Mammal. 89, 408418.

Kie, J.G., Matthiopoulos, J., Fieberg, J., Powell, R.A., Cagnacci, F., Mitchell, M.S., Gaillard, J.M., Moorcroft, P.R., 2010. The home-range concept: are traditional estimators still relevant with modern telemetry technology? Philos. T. R. Soc. B 365, 2221-2231.

Lamprecht, J., 1978. The relationship between food competition and foraging group size in some larger carnivores: a hypothesis. Tierpsychol. 46, 337-343.

Laundré, J.W., 2005. Puma energetics: a recalculation. J. Wildlife Manage. 69, 723-732.

Laundré, J.W., 2010. Behavioral response races, predator-prey shell games, ecology of fear, and patch use of pumas and their ungulate prey. Ecology 91, 29953007.

Laundré, J.W., Hernández, L., Streubel, D., Altendorf, K., González, C.L., 2000. Aging mountain lions using gum-line recession. Wildlife Soc. B 28, 963-966.

Logan, K.A., Sweanor, L.L., 2001. Desert Puma: Evolutionary Ecology and Conservation of an Enduring Carnivore. Island Press, Washington.
Logan, K.A., Sweanor, L.L., 2010. Behavior and social organization of a solitary carnivore. In: Hornocker, M., Negri, S. (Eds.), Cougar: Ecology and Conservation. University of Chicago Press, Chicago, pp. 105-117.

MacDonald, D.W., Loveridge, A.J., 2010. Biology and Conservation of Wild Felids. Oxford University Press, Oxford.

McRae, B.H., Beier, P., DeWald, L.E., Huynh, L.Y., Keim, P., 2005. Habitat barriers limit gene flow and illuminate historical events in a wide-ranging carnivore, the American puma. Mol. Ecol. 14, 1965-1977.

McLellan, B.N., 1989. Dynamics of a grizzly bear population during a period of industrial resource extraction: density and age-sex composition. Can. J. Zool. 67, 1856-1860.

Mohr, C.O., 1947. Table of equivalent populations of North American small mammals. Am. Midl. Nat. 37, 223-249.

Mosser, A., Packer, C., 2009. Group territoriality and the benefits of sociality in the African lion, Panthera leo. Anim. Behav. 78, 359-370.

Murphy, K., Ruth, T., 2010. Diet and prey selection of a perfect predator. In: Hornocker, M., Negri, S. (Eds.), Cougar: Ecology and Conservation. University of Chicago Press, Chicago, pp. 118-137.

Novaro, A.J., Funes, M.C., Walker, R.S., 2000. Ecological extinction of native prey of a carnivore assemblage in Argentine Patagonia. Biol. Conserv. 92, 25-33.

Quigley, H., Hornocker, M., 2010. Cougar population dynamics. In: Hornocker, M., Negri, S. (Eds.), Cougar: Ecology and Conservation. University of Chicago Press, Chicago, pp. 59-75.

Raedeke, K.J., 1979. Population dynamics and socio-ecology of the guanaco (Lama guanicoe) of Magallanes, Chile. Ph.D. Dissertation, Univ. Washington, 409 pp.

Riley, S.J., Nesslage, G.M., Maurer, B.A., 2004. Dynamics of early wolf and cougar eradication efforts in Montana: implications for conservation. Biol. Conserv. 119, 575-579.

Ruth, T., Murphy, K., 2010. Competition with other carnivores for prey. In Hornocker, M., Negri, S. (Eds.), Cougar: Ecology and Conservation. University of Chicago Press, Chicago, pp. 163-174.

Ruth, T.K., Haroldson, M.A., Murphy, K.M., Buotte, P.C., Hornocker, M.G., Quigley, H.B., 2011. Cougar survival and source-sink structure on Greater Yellowstone's Northern Range. J. Wildlife Manage. 75, 1381-1398.

Schmidt, K., 2008. Behavioural and spatial adaptation of the Eurasian lynx to a decline in prey availability. Acta Theriol. 53, 1-16.

Seaman, D.E., Powell, R.A., 1996. An evaluation of the accuracy of kernel density estimators for home range analysis. Ecology 77, 2075-2085.

Steel, R.G., Torrie, J.H., Dickey, D.A., 1997. Principles and Procedures of Statistics, 3rd ed. McGraw-Hill, New York.

Sunquist, M., Sunquist, F., 2002. Wild Cats of the World. University of Chicago Press, Chicago.

Thomas, L., Buckland, S.T., Rexstad, E.A., Laake, J.L., Strindberg, S., Hedley, S.L., Bishop J.R., Marques, T.A., Burnham, K.P., 2010. Distance software: design and analysis of distance sampling surveys for estimating population size. J. Appl. Ecol. 47, 5-14.

Torres, H., 1992. IUCN/SSC South American Camelid Specialist Group. Gland, 58 pp.

Walker, S., Novaro, A., 2010. The world's southernmost puma in Patagonia and the southern Andes. In: Hornocker, M., Negri, S. (Eds.), Cougar: Ecology and Conservation. University of Chicago Press, Chicago, pp. 91-99.

Williams, J.S., McCarthy, J.J., Picton, H.D., 1995. Cougar habitat use and food habits on the Montana Rocky Mountain Front. Intermt. J. Sci. 1, 16-28.

Wittmer, H.U., Corti, P., Saucedo, C., Galaz, J.L., 2010. Learning to count: adapting population monitoring for endangered huemul deer to meet conservation objectives. Oryx 44, 516-522.

Worton, B.J., 1989. Kernel methods for estimating the utilization distribution in home-range studies. Ecology 70, 164-168. 